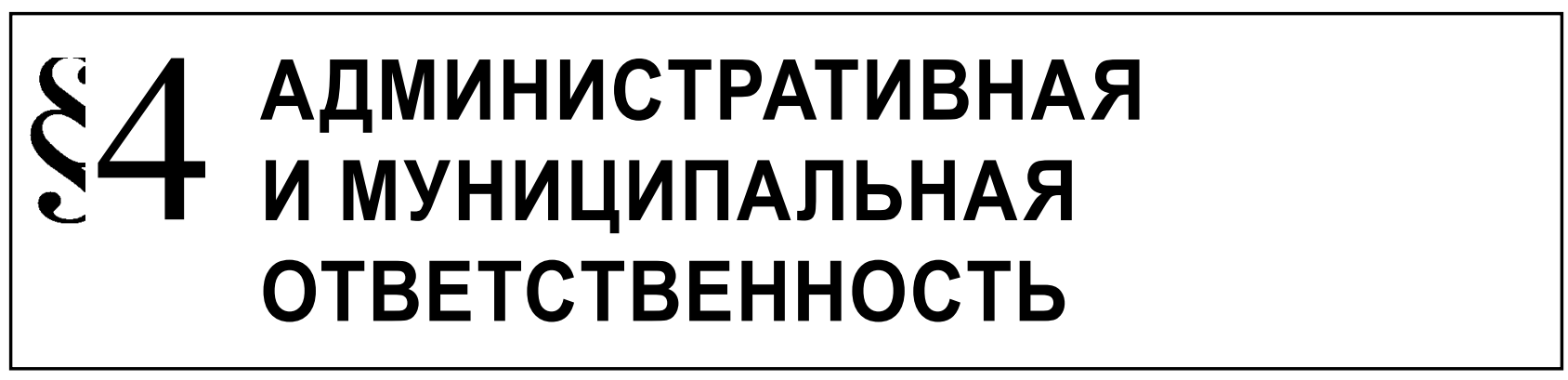

Серов А.C.

\title{
АДМИНИСТРАТИВНО-ПРОЦЕССУАЛЬНЫЕ ГАРАНТИИ УЧАСТНИКОВ ПРОИЗВОДСТВА ПО ДЕЛАМ ОБ АДМИНИСТРАТИВНЫХ ПРАВОНАРУШЕНИЯХ
}

Аннотация: Изучение административно-процессуального положения участников производства по делам об административных правонарушениях показывает, что проблема обеспечения прав и законных интересов личности в производстве по делам об административных правонарушениях имеет несколько основных аспектов в отношении: производства по делам об административных правонарушениях, применения мер административного принуждения в целом, деятельности государства по обеспечению прав и законных интересов физических и юридических лич в административно-правовой сфере. В Российской Федерации устанавливается система государственной защиты прав и свобод человека и гражданина, в том числе и потерпевшего от административного правонарушения. По мере развития административного законодательства, в деятельности государственных органов и должностных лиц, ведущих производство по делам об административных правонарушениях, произошло смещение от принципа охраны прав и интересов государства, общества и человека Методологическую основу работы составили современные достижения теории познания. В процессе исследования применялись общефилософский, теоретический, эмпирический методы (диалектика, системный метод, анализ, синтез, аналогия, дедукция, наблюдение, моделирование), традиционно правовые методы (формально-логический), методы, используемые в конкретно-социологических исследованиях (статистические, экспертные оценки и др.). Правовое положение участников производства по делам об административных правонарушениях характеризуется комплексом прав и обязанностей, базирующихся на конституционных правах и обязанностях личности, но, тем не менее, имеет свою специфику, дополнительные права и обязанности. Помимо этого, правовое положение участников производства по делу об административном правонарушении включает в себя юридическую ответственность, которая применяется в случае неисполнения или ненадлежащего исполнения ими своих обязанностей.

Ключевые слова: гарантия, процесс, участник, статус, регулирование, принуждение, организация, производство, стадия, личность.

\section{B} Российской Федерации устанавливается система государственной защиты прав и свобод человека и гражданина, в том числе и потерпевшего от административного правонарушения. По мере развития административного законодательства, в деятельности государственных органов и должностных лиц, ведущих производство по делам об административных правонарушениях, произошло смещение от принципа охраны прав и интересов государства, общества и человека ${ }^{1}$ к принципу защиты личности, общества и государства (ст. 1.2 КоАП РФ). Таким образом, на первое место вышла задача защиты прав и свобод именно человека, и лишь потом - общества и государства ${ }^{2}$.

См.: Севрюгин В.Е. Проблемы административного права. Тюмень, 1994. - С. 187.

2 См.: Новиков В.П. Физические и юридические лица как потерпевшие по делам об административных правонарушениях: Автореф. дис. ... канд. юрид. наук. - М., 2004. - С. 22. 
В связи с этим, исследуя административноправовое положение участников производства по делам об административных правонарушениях, нельзя оставить без внимания вопрос о роли и значении гарантий ${ }^{3}$.

Осуществление участниками производства по делам об административных правонарушениях принадлежащих им согласно КоАП РФ прав невозможно без создания и обеспечения государством реальных возможностей их практической реализации. Необходимо «не только продекларировать их права ... но и закрепить детально разработанный механизм их реализации. В законе должна быть последовательно проведена демократизация всего производства по делам об административных правонарушениях, исключающая ущемление прав участников процесса и обеспечивающая реальное восстановление прав в случае их нарушения» 4 . В этом как раз и проявляется социальное назначение гарантий.

По мнению А.С. Мордовца, термин «гарантии», судя по содержанию действующих норм, находится как бы «вне пределов видимости» законодателя, сводится к условиям..., привносится им через содержание юридической ответственности, то есть меры государственного принуждения 5 .

В недавнем прошлом в юридической науке проблеме гарантий уделялось достаточно много внимания. Ей было посвящено большое количество научных статей и монографий ${ }^{6}$, ибо проблема обеспечения и защиты прав человека находилась в центре идеологической борьбы между социализмом и капитализмом. Среди юристов было распространено мнение о том, что гарантии по своему содержанию и характеру действия могут подразделяться на общие и специальные (юриди-

\footnotetext{
3 Термин «гарантия» заимствован из французского языка и означает ручательство, обеспечение, условие, обеспечивающее что-либо // Словарь иностранных слов. - М., 1964. C. 114 .

4 Шергин А.П. Проблемы административно-деликтного права // Государство и право. - 1994. - № 8-9. - С. 62.

5 См.: Мордовец А.С. Социально-юридический механизм обеспечения прав человека и гражданина. — Саратов, 1996. С. 85; Филатова А.В. Гарантии административной ответственности граждан: Автореф. дис. ... канд. юрид. наук. Саратов, 2003. - C. 13.

6 См.: Витрук Н.В. Правовой статус личности в СССР. М., 1985. - С. 123; Боброва Н.А., Зражевская Т.Д. Ответственность в системе гарантий конституционных норм. Воронеж, 1985. - С. 156; Воеводин Л.Д. Юридический статус личности в России. - М., 1997. - С. 134.
}

ческие). Общие гарантии выступали в качестве определенных экономических, политических, социальных и идеологических условий и предпосылок, обеспечивающих возможность реализации прав и обязанностей. Под специальными (юридическими) гарантиями понимались правовые нормы, определяющие юридическими средствами конкретный порядок реализации и защиты прав и обязанностей.

Некоторые авторы проводят классификацию разновидностей гарантий прав потерпевшего в зависимости от государственного органа, их обеспечивающего ${ }^{7}$ гарантии со стороны должностных лич (органов) исполнительной власти, ведущих производство по делу о правонарушении; поднадзорные прокуратуре; судебные гарантии.

На наш взгляд, названные виды гарантий продолжают существовать и игнорировать их не следует. Между тем в современных условиях некоторым изменениям подвержены общие гарантии. Это обусловлено тем, что государство отказывается от прежней сверхидеологизации и кардинально изменяется его роль и функции в экономической сфере.

Среди общих гарантий правового положения участников производства по делам об административных правонарушениях можно выделить экономические гарантии. При их характеристике ограничимся указанием на то, что права и обязанности участников производства данной категории лиц, как и граждан России, могут быть реализованы и надежно обеспечены при наличии должного финансово-экономического обоснования.

Экономические гарантии - это материальные условия для фактической реализации прав и обязанностей участников производства по делам об административных правонарушениях. Они базируются на экономической системе Российской Федерации, основу которой составляют частная, государственная, муниципальная и иные формы собственности. Многообразие форм собственности является главной экономической гарантией участников производства по делам об административных правонарушениях, так как собственность в то же время представляет собой источник формирования и развития всей системы экономических гарантий во

См.: Новиков В.П. Физические и юридические лица как потерпевшие по делам об административных правонарушениях: Автореф. дис. ... канд. юрид. наук. - М., 2004. - С. 12. 
всех непосредственно конкретных проявлениях. В связи с этим представляется возможным провести знак равенства между правовым положением граждан вообще и правовым положением участников производства по делам об административных правонарушениях с точки зрения его обеспечения экономическими гарантиями ${ }^{8}$.

Потерпевший, свидетель, специалист, эксперт, переводчик и понятой, привлекаемые для участия в осуществлении процессуальных действий по делам об административных правонарушениях, имеют право на возмещение понесенных ими расходов в связи с их явкой по вызову в суд, орган, к должностному лицу, в производстве которых находится дело об административном правонарушении. Указанные расходы включают в себя расходы на проезд, расходы по найму жилого помещения и суточные.

Расходы на проезд включают в себя:

а) стоимость проезда до места вызова и обратно до места постоянного жительства;

б) страховые платежи по государственному обязательному страхованию пассажиров на транспорте;

в) оплату услуг по предварительной продаже проездных документов;

г) затраты на пользование постельными принадлежностями на железнодорожном транспорте;

д) стоимость проезда транспортом общественного пользования (кроме такси) к железнодорожной станции, пристани, аэропорту и автовокзалу.

Возмещение потерпевшим, свидетелям, специалистам, экспертам, переводчикам и понятым расходов на проезд производится на основании проездных документов, но не выше:

- $\quad$ для железнодорожного транспорта - стоимости проезда в купейном вагоне скорого фирменного поезда;

- $\quad$ для водного транспорта - стоимости проезда в каюте V группы морского судна регулярных транспортных линий и линий с комплексным обслуживанием пассажиров, в каюте II категории речного судна всех линий сообщения, в каюте I категории судна паромной переправы;

- $\quad$ для автомобильного транспорта - стоимости проезда в автотранспортном средстве общего пользования (кроме такси);

8 См.: Новиков В.П. Физические и юридические лица как потерпевшие по делам об административных правонарушениях: Автореф. дис. ... канд. юрид. наук. - М., 2004. - С. 22.
- $\quad$ для воздушного транспорта - стоимости проезда в салоне экономического класса.

Возмещение расходов по найму жилого помещения и выплата суточных потерпевшим, свидетелям, специалистам, экспертам, переводчикам и понятым за дни явки по вызову в суд, орган, к должностному лицу, в производстве которых находится дело об административном правонарушении, включая время в пути, выходные и праздничные дни, а также за время вынужденной остановки в пути, подтвержденной соответствующими документами, производятся в порядке, установленном нормативными правовыми актами Российской Федерации о возмещении расходов, связанных со служебными командировками на территории Российской Федерации работников организаций, финансируемых за счет средств федерального бюджета.

В настоящее время можно говорить о равных правах граждан и участников производства по делам об административных правонарушениях с точки зрения защиты их имущественных прав и т.д.

Политические гарантии правового положения участников производства по делам об административных правонарушениях напрямую зависят от основы государственного строя, политической системы общества. Важным достижением в политической сфере является провозглашение идеи формирования правового государства, проводимой на основе принципа разделения властей, принадлежности государственной власти народу, соблюдения и защиты прав и свобод человека и гражданина государством, широких возможностей для участия граждан в управлении делами государства и общества, реорганизации органов государственной власти и управления, создания в обществе правовых условий гласности и политического плюрализма.

Стабильный режим законности в условиях формирования правового государства может основываться лишь на прочных идеологических гарантиях, обеспечивающих приоритет общечеловеческих ценностей над государственными, верховенство права в общественной жизни.

Говоря о социальных гарантиях правового положения участников производства по делам об административных правонарушениях, мы имеем в виду процесс проведения различных преобразований в социальной сфере: в области материальных условий жизнедеятельности, условий труда и быта. Подтверждением этому является закрепленное в Конституции России положение о том, что 
Российская Федерация - социальное государство, политика которого направлена на создание условий, обеспечивающих достойную жизнь и свободное развитие человека.

Как уже отмечалось, важное место в системе условий и средств обеспечения правового положения участников производства по делам об административных правонарушениях принадлежит также юридическим гарантиям, то есть тем правовым средствам и способам, с помощью которых в российском обществе обеспечивается реализация прав граждан и выполнение ими своих обязанностей. Следует отметить, что в научной юридической литературе вопрос о понятии юридических (правовых) гарантий и об их составе решается далеко не однозначно.

Как утверждают одни авторы, к юридическим гарантиям следует отнести лишь юридические нормы определенной разновидности, так называемые нормативно-правовые средства обеспечения законности․ По мнению других ученых, в состав юридических гарантий, помимо нормативно-правовых средств обеспечения законности, необходимо также включить деятельность государственных органов (в некоторых случаях и общественных объединений), которая регулируется этими нормами ${ }^{10}$. Представители третьей точки зрения полагают, что юридические гарантии - это основанная на нормах права собственно деятельность государственных органов и общественных объединений ${ }^{11}$. И, наконец, некоторые ученые выражают точку зрения, являющуюся своеобразным синтезом рассмотренных позиций других авторов. Как утверждают они, к юридическим гарантиям следует относить определенные нормы права, основанную на них правоприменительную деятельность по обеспечению прав и свобод личности, а также индивидуальные юридические акты, в которых эта деятельность фиксируется ${ }^{12}$.

Наиболее убедительной из всех приведенных, на наш взгляд, является последняя точка зрения.

\footnotetext{
9 См.: Патюлин В.А. Государство и личность в СССР (проблемы взаимоотношений). - М., 1974. - С. 237-239.

10 См.: Недбайло П.Е. Система юридических гарантий применения советских правовых норм // Правоведение. 1981. — № 3. - С. $44-53$.

11 См.: Мицкевич А.В. Субъекты советского права. - М., 1962. - C. 83.

12 См.: Дюрягин И.Я. Применение норм советского права. Свердловск, 1973. - С. 197; Иванов В.А. Административноправовые гарантии неприкосновенности личности. - М., 1971. - C. 13.
}

Ее обоснованность, по нашему мнению, в первую очередь обуславливается функциональным назначением юридических гарантий, заключающимся в обеспечении фактической реализации и надежной охране прав личности. Исходя из этого, формальное закрепление в правовых нормах соответствующих предписаний само по себе еще не может обеспечить действительность юридических гарантий. Это достигается лишь на таких уровнях деятельности государственных органов (их должностных лиц), как: организация и обеспечение исполнения правовых предписаний, содержащих требования, направленные на обеспечение прав участников производства по делам об административных правонарушениях, осуществление деятельности по непосредственному исполнению этих предписаний, то есть реализация юридических гарантий. Только в процессе реализации, отмечает А.П. Коренев, «административно-правовые нормы достигают своей цели, субъективные права и обязанности воплощаются в поведение конкретных участников управленческих отношений» ${ }^{13}$.

Рассматривая юридические (правовые) гарантии правового положения участников производства по делам об административных правонарушениях, нельзя не упомянуть о том, что все нормы российского права образуют целостную иерархически разветвленную систему, между элементами которой существуют структурные, функциональные и другие связи. Благодаря наличию таких связей реализация каждой конкретной правовой нормы непосредственно зависит от действительности других норм права, которые тем или иным образом с нею связаны.

Так, реально, неприкосновенность личности (ст. 22 Конституции России) обуславливается действием многочисленных норм уголовного, уголовно-процессуального и административного права. Поэтому, как справедливо отмечается в литературе, «в широком смысле любая юридическая норма, поддерживающая, «обслуживающая» действие другой нормы, может рассматриваться как гарантия последней» ${ }^{14}$. Вместе с тем понятие юридических гарантий в узком, специфическом значении должно охватывать лишь те нормы, у которых обеспечение реализации других правовых норм явля-

\footnotetext{
13 Коренев А.П. Нормы административного права и их применение. - М., 1978. - С.13.

14 Рабинович П.М. Упрочнение законности - закономерность социализма. Вопросы теории и методологии. - Львов, 1975. - C. 239.
} 
ется непосредственной (ближайшей) и основной целью, то есть такие, у которых четко проявляется важная относительно самостоятельная функциональная специализация: гарантирование реальности, выполнимости, действительности правовых предписаний.

Характеризуя юридические гарантии правового положения участников производства по делам об административных правонарушениях, нельзя не отметить, что правовые гарантии от иных способов обеспечения прав и обязанностей участников производства по делам об административных правонарушениях отличаются особой, предусмотренной законом процедурой применения. Но вместе с тем юридические гарантии не существуют изолированно от экономических, политических, идеологических и социальных, а выступают в неразрывной связи с ними и на их основе.

Так, юридические (правовые) гарантии правового положения участников производства по делам об административных правонарушениях, являясь в определенном смысле производными от экономических, политических, идеологических, социальных гарантий, будучи весьма многочисленными и многообразными, как было подмечено выше, обладают общим свойством - все они выражены и закреплены в законах и подзаконных нормативных правовых актах, в тех нормах, которые раскрывают и конкретизируют права и обязанности участников производства по делам об административных правонарушениях, а также устанавливают порядок их осуществления. Однако непосредственными правовыми гарантиями являются лишь правовые нормы, определяющие средства и способы, при помощи которых достигаются: беспрепятственное пользование правами и исполнение обязанностей, защита прав и восстановление их в случае нарушения.

Рассматривая систему юридических гарантий прав и обязанностей личности в Российской Федерации, Н.В. Витрук подразделяет их на две основные группы: гарантии реализации прав и исполнения обязанностей и гарантии их охраны. К первой группе автор относит: «закрепленные законодательством: конкретизацию пределов (границ) прав, обязанностей и законных интересов; юридические факты, с которыми связывается их реализация; процессуальные формы реализации прав, обязанностей и законных интересов; меры поощрения и льготы для стимулирования правомерной инициативной их реализации. Ко второй группе относятся: меры надзора и кон- троля за правомерностью поведения субъектов права с целью выявления субъектов правонарушений; меры правовой защиты, меры юридической ответственности, меры пресечения и другие правоохранительные меры; процессуальные формы охраны прав и обязанностей (включая формы применения правоохранительных мер); нормы профилактики и предупреждения правонарушений». ${ }^{15}$

Данная классификация наиболее приемлема для целей научного исследования административно-процессуального положения участников производства по делам об административных правонарушениях и имеет большую практическую направленность. Уже из названия видно, что гарантии реализации направлены на создание для участников производства по делам об административных правонарушениях оптимальных условий реализации своих прав и выполнения возложенных обязанностей. К ним относятся: правовые средства, при помощи которых определяются (конкретизируются) границы, пределы прав и обязанностей правового положения участников производства по делам об административных правонарушениях, юридические факты, с которыми связывается их реализация, меры стимулирования реализации и некоторые другие ${ }^{16}$.

Необходимость в защите прав участников производства по делам об административных правонарушениях возникает в случае неисполнения должностными лицами своих обязанностей или злоупотребления правом, когда появляется препятствие к реализации административно-процессуального статуса участниками производства по делам об административных правонарушений. Кроме этого, необходимость в защите прав участников производства по делам об административных правонарушениях возникает и в случае возникновения спора о наличии самого права или обязанности. Обобщая сказанное, можно определить, что гарантии защиты правового положения участников производства по делам об административных правонарушениях преимущественно направлены на установление препятствий в нормальном осуществлении прав и обязанностей участниками рассматриваемого административного произ-

15 Воеводин Л.Д. Юридический статус личности в России. M., 1997. - С. 221.

16 См.: Витрук Н.В. Основы теории правового положения личности в социалистическом обществе. - М., 1979. C. 207. 
водства. В число гарантий защиты входят меры правовой защиты: процессуальные формы охраны прав и обязанностей участников производства по делам об административных правонарушениях, меры профилактики и предупреждения правонарушений и некоторые другие. ${ }^{17}$ Разумеется, что при всем различии в содержании и отмеченной специфике, гарантии реализации и защиты тесно взаимосвязаны между собой, так как только в своей совокупности они могут создать надежный и реальный механизм обеспечения прав и обязанностей участников производства по делам об административных правонарушениях.

Юридические гарантии правового положения участников производства по делам об административных правонарушениях, основываясь на изложенных выше общих положениях о гарантиях прав личности в России, непосредственно связаны с применением норм административного права. Их реализация носит стадийный характер и выражается в деятельности должностных лиц органов административной юрисдикции, прокуратуры, суда и самих участников производства по делам об административных правонарушениях.

Анализируя стадии (этапы) развития принадлежащих участникам производства по делам об административных правонарушениях прав и обязанностей, ряд ученых относят к ним:

a) правоспособность, то есть субъективную возможность каждого из участников обладать определенным комплексом прав;

б) правовой статус, то есть закрепленные в нормативных правовых актах права и обязанности, которые пока не реализованы в соответствующих правоотношениях;

в) правомочия, то есть реализуемые участниками производства по делам об административных правонарушениях права в конкретных правоотношениях ${ }^{18}$.

Возможность участниками производства по делам об административных правонарушениях обладать определенным комплексом прав гарантируется Конституцией России, КоАП России и рядом иных нормативных правовых актов.

Стадии приобретения субъективного права, характеризующего непосредственно правовое положение участников производства по делам об

17 Там же.

18 См.: Ямпольская Ц.А. О субъективных правах советских граждан и их гарантиях // Вопросы советского государственного права. - М., 1975. - С. 78. административных правонарушениях, требуют уже значительной большей конкретизации. Иначе говоря, гарантии на данной стадии должны получить уже форму более конкретных правовых установлений (КоАП России). Для этого необходимо принимать законы, постановления и другие нормативные правовые акты, определяющие условия, при которых каждый из участников производства по делам об административных правонарушениях приобретает конкретные субъективные права и несет определенные обязанности.

Задача конкретизации конституционных положений чрезвычайна важна в связи с тем, что детальная правовая регламентация конституционных прав в действующем законодательстве, установление правовых средств их охраны и защиты - есть необходимое условие реализации общих положений, содержащихся в Конституции ${ }^{19}$. С другой стороны, конституционные права участников производства по делам об административных правонарушениях в силу своей отраслевой конкретизации определяют непосредственные пределы прав и обязанностей указанных субъектов.

Реализация правового положения участников производства по делам об административных правонарушениях ставит также вопрос о четкой организации деятельности органов административной юрисдикции, призванных защищать права заинтересованных участников производства по делам об административных правонарушениях. В этой связи ряд ученых справедливо акцентируют внимание на важности и необходимости сегодня не только правовых и общих, но и организационных гарантий правового положения участников производства по делам об административных правонарушениях ${ }^{20}$.

В общих чертах под организационными гарантиями понимают специальную организационную деятельность органов публичного управления, которую они должны выполнять для обеспечения наиболее полного и всестороннего осуществления принадлежащих личности прав и исполнения возложенных обязанностей.

Правоохранительная деятельность органов административной юрисдикции в данном случае осуществляется целой системой организационно-

\footnotetext{
19 См.: Патюлин В.А. Государство и личность в СССР (проблемы взаимоотношений). - М., 1968. - С. 134.

20 См.: Лучин B.О. Реализация конституционных норм: общее и особенное // Конституционная реформа в СССР: актуальные проблемы. - М ., 1991. - С. 46-47.
} 
правовых средств и мер в самых различных формах: в процессе руководства вышестоящих органов деятельностью нижестоящих органов и должностных лиц в целях строжайшего соблюдения законности; посредством издания нормативных правовых актов, в частности связанных с реализацией предоставленных участникам производства по делам об административных правонарушениях прав и возложенных на них обязанностей; в процессе приема и рассмотрения вышестоящими органами административной юрисдикции жалоб на незаконные действия и акты должностных лиц органов административной юрисдикции. Согласно КоАП РФ праву лица, привлекаемого к ответственности, потерпевшего на обжалование действий должностных лиц (органов) соответствует обязанность таких лиц (органов) рассмотреть жалобу и принять по ней решение. Речь, разумеется, не идет об обязанности удовлетворить жалобу. Реализация права жаловаться заключается в уведомлении органа государственной власти о допущенном нарушении интересов подателя жалобы и формулировке просьбы ликвидировать это нарушение ${ }^{21}$. При получении жалобы суд обязан её рассмотреть в десятидневный срок (ст. 30.5 КоАП РФ). При этом проверяется не целесообразность самой жалобы, а законность и обоснованность вынесенного постановления. Главным принципом судебного контроля за законностью производства по делу об административном правонарушении является принцип альтернативности выбора адресата жалобы ${ }^{22}$.

Организационные гарантии также реализуются при применении мер дисциплинарного воздействия к лицам, нарушившим права заинтересованных участников производства по делам об административных правонарушениях, а также прав участников, которые содействуют осуществлению производства по делу об административном правонарушении.

Повседневная, целенаправленная и организационная работа органов публичного управления по реализации законов и изданных на их основе административно-правовых актов, широкая работа по предупреждению возможных случаев нарушений законности составляют основу админи-

\footnotetext{
21 См.: Александров С.А. Правовые гарантии возмещения ущерба в уголовном процессе. - Горький, 1976. - С. 75.

22 См.: Скитович В. Процессуальные особенности рассмотрения дел по жалобам на действия административных органов и должностных лиц // Советская юстиция. - 1985. № 11 . - С. $22-24$.
}

стративной охраны прав участников производства по делам об административных правонарушениях. Законодательство предусматривает дисциплинарную и уголовную ответственность должностных лиц за правонарушения, связанные с их служебным положением, в том числе и за нарушение прав участников производства по делам об административных правонарушениях.

Опыт показывает, что такой подход является вполне оправданным и правомерным, так как четкая и научно обоснованная организационная деятельность во многом определяет эффективность всей системы гарантий, существующей в государстве. Красноречивым подтверждением этому являются многочисленные примеры из деятельности различных органов государственной власти, когда при наличии одинаковых возможностей в одних случаях права и свободы личности реализуются быстро и точно, а в других - имеются нарушения этих прав и различные проволочки.

Большую роль в защите прав участников производства по делам об административных правонарушениях играют судебные органы и органы прокуратуры. Суды рассматривают жалобы лица, в отношении которого ведется производство по делу об административном правонарушении, а также потерпевшего в связи с осуществлением производства, а также в связи с принятым решением. Рассматривая жалобу, суды контролируют законность актов и действий органов административной юрисдикции путем проверки их соответствия требованиям КоАП РФ.

Органами прокуратуры права участников производства по делам об административных правонарушениях охраняются теми же формами и методами надзорной деятельности, что и права личности вообще. Осуществляя общий надзор за деятельностью органов административной юрисдикции и их должностных лиц, органы прокуратуры проверяют правильность применения и соблюдения законодательства об административных правонарушениях. Значительное место в работе прокуратуры занимает надзор за соблюдением порядка, применения мер обеспечения производства по делам об административных правонарушениях. В случае выявления конкретных нарушений законности в деятельности органов административной юрисдикции органы прокуратуры обязаны применять соответствующие меры прокурорского реагирования. Обобщая вышеизложенное, необходимо сказать, что объектами гарантий являются: соблюдение прав лица, 
привлекаемого к административной ответственности (ст. 1.4 КоАП РФ), охрана прав граждан, привлекаемых к административной ответственности (ст. 1.5 КоАП РФ), защита прав и свобод граждан, привлекаемых к административной ответственности (ст. 1.6 КоАП РФ). Таким обра- зом, гарантии имеют важное значение для характеристики правового положения участников производства по делам об административных правонарушениях, причем важно подчеркнуть, что они тесно взаимосвязаны между собой и взаимодополняют друг друга ${ }^{23}$.

\section{Библиография:}

1. Александров С.А. Правовые гарантии возмещения ущерба в уголовном процессе.-Горький, 1976.

2. Боброва Н.А., Зражевская Т.Д. Ответственность в системе гарантий конституционных норм.-Воронеж, 1985.

3. Витрук Н.В. Правовой статус личности в СССР.-М., 1985.

4. Воеводин Л.Д. Юридический статус личности в России.-М., 1997.

5. Дюрягин И.Я. Применение норм советского права.-Свердловск, 1973.

6. Иванов В.А. Административно-правовые гарантии неприкосновенности личности.-М., 1971.

7. Коренев А.П. Нормы административного права и их применение.-М., 1978.

8. Костенников М.В., Куракин А.В. Актуальные проблемы административного права. - М., 2013.

9. Лучин В.О. Реализация конституционных норм: общее и особенное // Конституционная реформа в СССР: актуальные проблемы.-М ., 1991.

10. Мицкевич А.В. Субъекты советского права.-М., 1962.

11. Мордовец А.С. Социально-юридический механизм обеспечения прав человека и гражданина.-Саратов, 1996.

12. Недбайло П.Е. Система юридических гарантий применения советских правовых норм // Правоведение.-1981.-№ 3.

13. Новиков В.П. Физические и юридические лица как потерпевшие по делам об административных правонарушениях: Автореф. дис. ... канд. юрид. наук.-М., 2004.

14. Патюлин В.А. Государство и личность в СССР (проблемы взаимоотношений).-М., 1968.

15. Рабинович П.М. Упрочнение законности-закономерность социализма. Вопросы теории и методологии.-Львов, 1975.

16. Скитович В. Процессуальные особенности рассмотрения дел по жалобам на действия административных органов и должностных лиц // Советская юстиция.-1985.-№ 11.

17. Севрюгин В.Е. Проблемы административного права.-Тюмень, 1994.

18. Филатова А.В. Гарантии административной ответственности граждан: Автореф. дис. ... канд. юрид. наук.-Саратов, 2003.

19. Шергин А.П. Проблемы административно-деликтного права // Государство и право.-1994.-№ 8-9.

20. Ямпольская Ц.А. О субъективных правах советских граждан и их гарантиях // Вопросы советского государственного права.-М., 1975.

21. Костенников М.В., Куракин А.В. Административный процесс и его реализация в деятельности полиции // Полицейская деятельность.-2013.-3.-C. 155-170. DOI: 10.7256/2222-1964.2013.3.8995.

22. Куракин А.В., Костенников М.В. Административный процесс и его реализации в деятельности полиции // NB: Российское полицейское право.-2013.-4.-C. 1-44. DOI: 10.7256/2306-4218.2013.4.9250. URL: http://www.e-notabene.ru/pm/article_9250.html

23. В.Д. Плесовских Тенденции развития федерального административно-деликтного права и законодательства // Право и политика.-2012.-12.-С. 1990-1994.

24. Д.А. Липинский. Правонарушение как фактическое основание юридической ответственности. // Право и политика.-2013.-№ 2.-C. 208-217. DOI: .10.7256/1811-9018.2013.02.

23 См.: Новиков В.П. Физические и юридические лица как потерпевшие по делам об административных правонарушениях: Автореф. дис. ... канд. юрид. наук. - М., 2004. C. 22 . 


\section{References:}

1. Aleksandrov S.A. Pravovye garantii vozmeshcheniya ushcherba v ugolovnom protsesse.-Gor'kii, 1976.

2. Bobrova N.A., Zrazhevskaya T.D. Otvetstvennost' v sisteme garantii konstitutsionnykh norm.-Voronezh, 1985.

3. Vitruk N.V. Pravovoi status lichnosti v SSSR.-M., 1985.

4. Voevodin L.D. Yuridicheskii status lichnosti v Rossii.-M., 1997.

5. $\quad$ Dyuryagin I.Ya. Primenenie norm sovetskogo prava.-Sverdlovsk, 1973.

6. Ivanov V.A. Administrativno-pravovye garantii neprikosnovennosti lichnosti.-M., 1971.

7. Korenev A.P. Normy administrativnogo prava i ikh primenenie.-M., 1978.

8. Kostennikov M.V., Kurakin A.V. Aktual'nye problemy administrativnogo prava. - M., 2013.

9. Luchin V.O. Realizatsiya konstitutsionnykh norm: obshchee i osobennoe // Konstitutsionnaya reforma $\mathrm{v}$ SSSR: aktual'nye problemy.-M ., 1991.

10. Mitskevich A.V. Sub"ekty sovetskogo prava.-M., 1962.

11. Mordovets A.S. Sotsial'no-yuridicheskii mekhanizm obespecheniya prav cheloveka i grazhdanina.-Saratov, 1996.

12. Nedbailo P.E. Sistema yuridicheskikh garantii primeneniya sovetskikh pravovykh norm // Pravovedenie.-1981.-№ 3.

13. Novikov V.P. Fizicheskie i yuridicheskie litsa kak poterpevshie po delam ob administrativnykh pravonarusheniyakh: Avtoref. dis. ... kand. yurid. nauk.-M., 2004.

14. Patyulin V.A. Gosudarstvo i lichnost' v SSSR (problemy vzaimootnoshenii).-M., 1968.

15. Rabinovich P.M. Uprochnenie zakonnosti-zakonomernost' sotsializma. Voprosy teorii i metodologii.-L'vov, 1975.

16. Skitovich V. Protsessual'nye osobennosti rassmotreniya del po zhalobam na deistviya administrativnykh organov i dolzhnostnykh lits // Sovetskaya yustitsiya.-1985.-№ 11.

17. Sevryugin V.E. Problemy administrativnogo prava.-Tyumen', 1994.

18. Filatova A.V. Garantii administrativnoi otvetstvennosti grazhdan: Avtoref. dis. ... kand. yurid. nauk.-Saratov, 2003.

19. Shergin A.P. Problemy administrativno-deliktnogo prava // Gosudarstvo i pravo.-1994.-№ 8-9.

20. Yampol'skaya Ts.A. O sub"ektivnykh pravakh sovetskikh grazhdan i ikh garantiyakh // Voprosy sovetskogo gosudarstvennogo prava.-M., 1975.

21. Kostennikov M.V., Kurakin A.V. Administrativnyi protsess i ego realizatsiya v deyatel'nosti politsii // Politseiskaya deyatel'nost'.-2013.-3.-C. 155-170. DOI: 10.7256/2222-1964.2013.3.8995.

22. Kurakin A.V., Kostennikov M.V. Administrativnyi protsess i ego realizatsii v deyatel'nosti politsii // NB: Rossiiskoe politseiskoe pravo.-2013.-4.-C. 1-44. DOI: 10.7256/2306-4218.2013.4.9250. URL: http://www.enotabene.ru/pm/article_9250.html

23. V.D. Plesovskikh Tendentsii razvitiya federal'nogo administrativno-deliktnogo prava i zakonodatel'stva // Pravo i politika.-2012.-12.-C. 1990-1994.

24. D.A. Lipinskii. Pravonarushenie kak fakticheskoe osnovanie yuridicheskoi otvetstvennosti. // Pravo i politika.-2013.-№ 2.-C. 208-217. DOI: .10.7256/1811-9018.2013.02. 